\title{
The Leaching of Iron and Loss of Phosphate in Acid Sulphate Soil Due to Rice Straw and Phosphate Fertilizer Application
}

\author{
Arifin Fahmi ${ }^{1}$, Bostang Radjagukguk ${ }^{2}$ and Benito Heru Purwanto ${ }^{2}$ \\ ${ }^{1}$ Indonesian Swampland Agriculture Research Institute (ISARI / BALITTRA). Jl. Kebun Karet, \\ Loktabat Utara, Banjarbaru, South Kalimantan, Indonesia. Tel :+62-08125112882, \\ e-mail: fahmi_nbl@yahoo.co.id \\ ${ }^{2}$ Soil Science Division, Faculty of Agriculture, Gadjah Mada University, Bulaksumur Campuss, \\ Yogyakarta, Indonesia.
}

Received 10 May 2011 / accepted 15 November 2011

\begin{abstract}
Low phosphorus $(\mathrm{P})$ availability and high iron $(\mathrm{Fe})$ concentration are the dominant characteristics of acid sulphate soils (ASS). Optimum agricultural management practices are required to leach the excess $\mathrm{Fe}^{2+}$ and to prevent or minimize loss of $\mathrm{P}$ from the soil in order to obtain conditions favorable for rice growth. The aim of this experiment was to study the effect of organic matter (OM) application in the form of rice straw (RS) on leaching of Fe and loss of $\mathrm{P}$ in an acid sulphate soil. The experiment was conducted in the glasshouse consisting of three treatment factors utilizing the completely randomized design with three replications. The first factor was soil condition consisting of continuous application of RS and without RS during the past five years. The second factor was application of fresh RS consisting of fresh RS application and without fresh RS application, whereas the third factor was P application consisting of three rates of SP-36 fertilizer (0.5, 1.0 and 1.5 times of the recommended rate). The results showed that RS application was effective in preventing P loss from the soil at 6 weeks after planting (WAP) and decreased the $\mathrm{pH}$ of leachate at all observations time but it increased $\mathrm{Fe}^{2+}$ concentration in leachate $\left(0.07-0.42 \% \mathrm{Fe}^{2+}\right.$ in the soil were leached or 2-5 folds higher than without RS application).
\end{abstract}

Keywords: Acid sulphate soil, Fe, leaching, phosphate, rice straw

\section{INTRODUCTION}

Low soil $\mathrm{pH}$, low $\mathrm{P}$ availability and high $\mathrm{Fe}^{2+}$ concentration are the dominant characteristics of acid sulphate soils (ASS). The large amount of Fe in the soil solution may be toxic to rice, and the critical concentration for the occurrence of $\mathrm{Fe}^{2+}$ toxicity is $>500 \mathrm{mg} \mathrm{Fe}^{2+} \mathrm{kg}^{-1}$ in the soil (Audebert 2006). The creation of optimum soil $\mathrm{pH}$, adequate available nutrients and low concentrations of toxic elements in the soil are required in the reclamation of ASS for agriculture.

The high concentration of $\mathrm{Fe}^{2+}$ in the ASS may be depressed with application of $\mathrm{OM}$ and proper water management. Concentration of $\mathrm{Fe}^{2+}$ in the soil solution is strongly influenced by soil OM and soil water content. Iron in the soil solution may be fixed and reduced by OM, thereby increasing its mobility and reducing its concentration (Reddy and De Laune 2008). Soil OM promotes increased $\mathrm{Fe}^{2+}$ mobility and complex formation thereby increasing

J Trop Soils, Vol. 17, No. 1, 2012: 19-24 ISSN 0852-257X leaching of $\mathrm{Fe}^{2+}$ and increasing $\mathrm{P}$ availability (Tan 2008). Consequently, the application of OM may lead to nutrient loss from the soil through increased solubility (Watanabe et al. 2009). However, soil OM content has also an important role in relation to $\mathrm{P}$ sorption capacity of soils (Kang et al. 2009). Ojekami et al. (2011) shows high rate of manure application may promote lost of $\mathrm{P}$ through leaching, in addition Van-Es et al. (2004) reports that 0.504 $\mathrm{mg} \mathrm{L}^{-1}$ of $\mathrm{P}$ was lost from the soil after manure application.

Water management plays a key role in improving the quality and productivity of ASS. In flooded condition, $\mathrm{Fe}^{2+}$ concentration will increase which may reach toxic levels to plants such as rice. On the other hand, with soil drainage, the pyrite will be oxidized leading to soil acidification. Optimum agricultural management practices are required to leach the excess $\mathrm{Fe}^{2+}$ and to prevent or minimize loss of $\mathrm{P}$ from the soil in order to obtain conditions favorable for rice growth.

The objective of this experiment was to determine the effect of OM application in the form of RS on the leaching of $\mathrm{Fe}^{2+}$ and $\mathrm{P}$ loss in the ASS. 
Table 1. Selected chemical properties of acid sulphate soils used in the experiment

\begin{tabular}{lcc}
\hline \multirow{2}{*}{ Soil property } & \multicolumn{2}{c}{ Acid sulphate soils } \\
\cline { 2 - 3 } & Without application of RS & Continuous application of RS \\
\hline $\mathrm{pH}\left(\mathrm{H}_{2} \mathrm{O}\right)$ & 4.2 & 3.9 \\
$\mathrm{P}\left(\mathrm{mg} \mathrm{PO}_{4}^{3-} \mathrm{kg}^{-1}\right)$ & 14.0 & 17.3 \\
$\mathrm{Fe}\left(\mu \mathrm{g} \mathrm{Fe}^{2+} \mathrm{kg}^{-1}\right)$ & 444 & 445 \\
\hline
\end{tabular}

\section{MATERIALS AND METHODS}

\section{Study Site and Design}

The experiment was conducted in the glasshouse, soils representing the surface $0-15 \mathrm{~cm}$ were sampled from the Belandean Research Station, located in Barito Kuala District, South Kalimantan. The experiment consisted of three treatment factors arranged in the completely randomized design with three replications. The first factor was soil condition (T) consisting of continuous application of RS $\left(\mathrm{t}_{2}\right)$ and without RS during the past five years $\left(\mathrm{t}_{1}\right)$. The second factor was fresh application of RS (B) consisting of fresh RS application $\left(b_{1}\right)$ and without fresh RS application $\left(b_{0}\right)$, whereas the third factor was $\mathrm{P}$ fertilizer application $(\mathrm{F})$ consisting of three rates of SP-36, i.e. $0.5 \times$ the recommended rate $\left(\mathrm{f}_{1}\right)$ $\left(0.275 \mathrm{~g} \mathrm{pot}^{-1}\right.$ or equivalent to $\left.100 \mathrm{~kg} \mathrm{SP}-36 \mathrm{ha}^{-1}\right), 1.0$ $\times$ the recommended rate $\left(\mathrm{f}_{2}\right)\left(0.550 \mathrm{~g} \mathrm{pot}^{-1}\right.$ or equivalent to $\left.200 \mathrm{~kg} \mathrm{SP}-36 \mathrm{ha}^{-1}\right)$ and $1.5 \times$ the recommended rate $\left(\mathrm{f}_{3}\right)\left(0.825 \mathrm{~g} \mathrm{pot}^{-1}\right.$ or equivalent to $\left.300 \mathrm{~kg} \mathrm{SP}-36 \mathrm{ha}^{-1}\right)$.

\section{Planting and Maintaining}

Five kilogram of fresh soils from the field were placed into plastic pots. To the pots with RS application treatment $\left(\mathrm{b}_{1}\right), 2.5 \mathrm{~g}$ of fresh RS was added, and subsequently rice seedlings (aged 2 weeks) were planted in the pots. Sufficient amount of water obtained from the river was added into each pot such that the water level was $3 \mathrm{~cm}$ above the soil surface. Three days after planting, $0.275 \mathrm{~g}$ pot $^{-1}$ each of urea and $\mathrm{KCl}$ were applied as basal fertilizers to the soil in the pot, while SP-36 was added at rates according to treatments. Throughout the duration of the experiment, aquadest was regularly added into each pot in order to maintain the water level. Water in the pots was drained at 2, 4, 6 and $8 \mathrm{WAP}$ and replaced with fresh river water. Water in the pot drained trough a small pipe (outlet) on the bottom of plastic pot. The leached was interceped and retained in a bottle below the plastic pots and leaching ended after it was stopped dropping, then leached in the bottle was divided into the three water samples, each of them was used

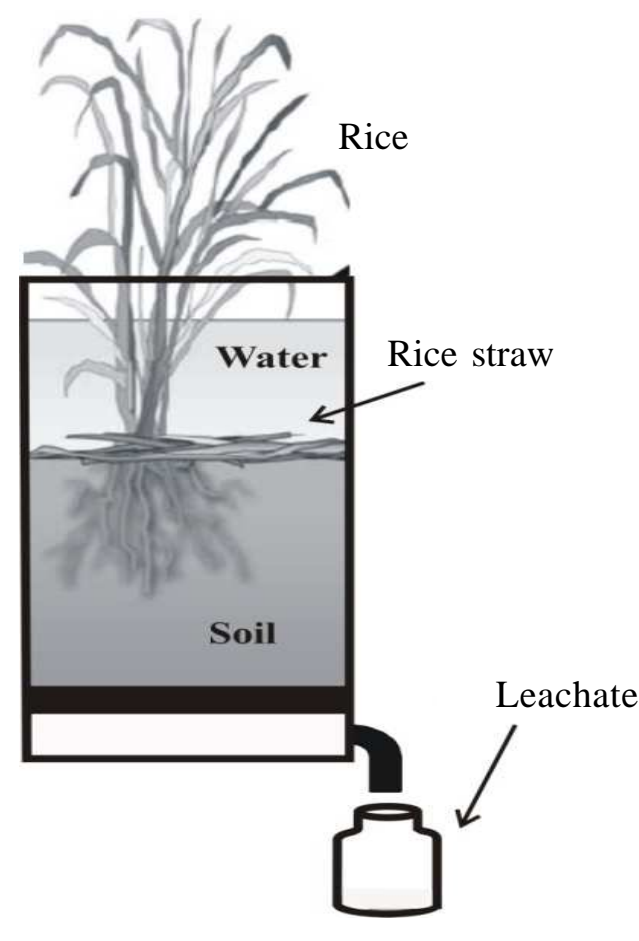

Figure 1. Pot experiment design.

for measurement of $\mathrm{pH}$, concentration $\mathrm{P}$ and $\mathrm{Fe}^{2+}$ in leachate.

\section{Measurement of Leachate}

The $\mathrm{pH}$ of leachate and $\mathrm{Fe}^{2+}$ concentration in leachate measured immediately after sampling time, $\mathrm{pH}$ of leachate measured with $\mathrm{pH}$-meter equipment "Orion 410 A Plus". Similar with $\mathrm{pH}$ of leachate, soluble $\mathrm{P}$ and $\mathrm{Fe}^{2+}$ concentration in leachate shall be direct determined (Balai Penelitian Tanah 2005). Before measurement, leachate was filtered by Whatman No. 42. Soluble $\mathrm{Fe}^{2+}$ in leachate was determined with Atomic Absorption Spectrofotometer "GBC 933 Plus", whereas P concentrations in the leachate was analyzed with Molybdate ammonia methods using "Spectronic 20 from Bosch and Lomb" (Balai Penelitian Tanah 2005).

\section{Data Analysis}

Only the main effects of RS application on the $\mathrm{pH}$ of leachate and $\mathrm{Fe}^{2+}$ concentration in the leachate were statistically significant. Therefore, 
they were analyzed by the Analysis of Variance (ANOVA) method and presented in a scatter form. Since there were no significant effects of treatments, data of $\mathrm{P}$ concentration in leachate were analyzed by descriptive statistical analysis and by calculation of means and standard error. The correlations of $\mathrm{pH}$ of leachate and $\mathrm{Fe}^{2+}$ and $\mathrm{P}$ concentrations in the leachate with $\mathrm{pH}$ of the soil and $\mathrm{Fe}^{2+}$ and $\mathrm{P}$ concentrations in the soil were obtained by regression analysis, for which data of soil $\mathrm{pH}$, and $\mathrm{Fe}^{2+}$ and $\mathrm{P}$ concentrations in the soil.

\section{RESULTS AND DISCUSSION}

\section{Chemical Properties of River Water Used}

Even though river water used in the experiment was collected at highest tide with the expectation that at the time of highest tide the water quality is at its best, in reality the $\mathrm{pH}$ of the river water remained very low (very acid), and at 2 and 6 WAP the $\mathrm{Fe}$ concentration of the river water remained high (Table 2). This indicated that soluble Fe was carried away from surrounding areas downstream towards the sea. Haraguchi (2004) reported the influence of sulfidic material or ASS in the areas surrounding rivers on the water $\mathrm{pH}$ and contents of $\mathrm{Fe}^{2+}$ and other minerals in the river water. Based on United State Environmental Agency (USEPA) (1986), the phosphate contents of the river water used as measured at 2 and 4 WAP were well below the critical level for environmental pollution (a maximum of $25-50 \mathrm{mg} \mathrm{kg}^{-1}$ ). Hence, the values were considered low, and the presence of phosphate would indicate that the river water had a potential to be a supplementary source of $\mathrm{P}$ to plants.

\section{The Effects of Rice Straw Application on the Leaching of $\mathrm{Fe}$}

Concentration of $\mathrm{Fe}^{2+}$ in leachate increased consistently only with fresh RS application (Table 3 and Figure 2). Increasing concentration of $\mathrm{Fe}^{2+}$ in the leachate with the application of fresh RS is considered to be related to the increase of $\mathrm{Fe}^{2+}$ solubility and mobility (Krachler et al. 2005). The presence of OM increases the mobility and solubility of Fe through reduction reaction (Kongchum 2005; Fuss et al. 2011) and chelation (Karlsson and Persson 2010). Reduced form of Fe is more mobile than the oxidized form, which facilitates its leaching

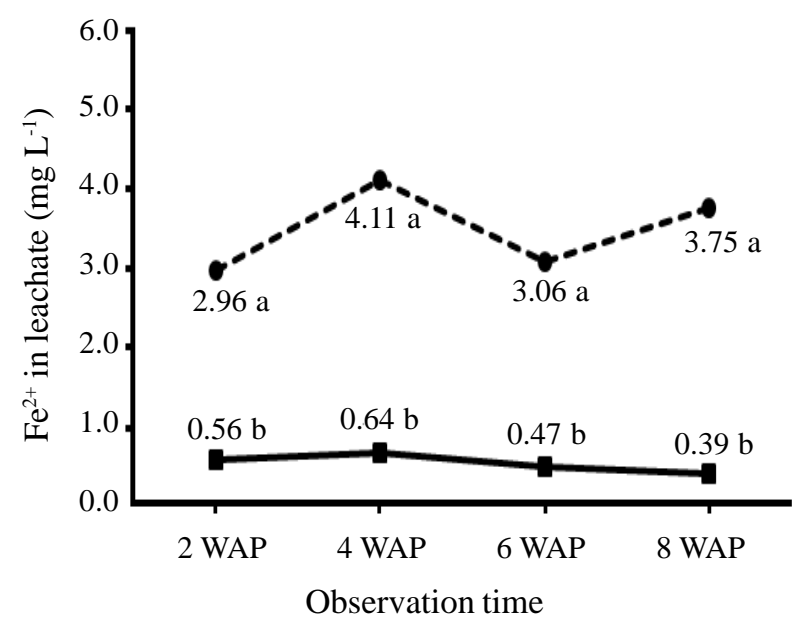

Figure 2. The effect of RS application as main factor on $\mathrm{Fe}^{2+}$ concentration in leachate. The values that followed by a same letter in a same observation time is not different base on $5 \%$ level of DMRt. $\rightarrow=$ Without fresh RS and $\boldsymbol{\bullet} \boldsymbol{\bullet} \cdot \boldsymbol{\bullet}=$ with Fresh RS.

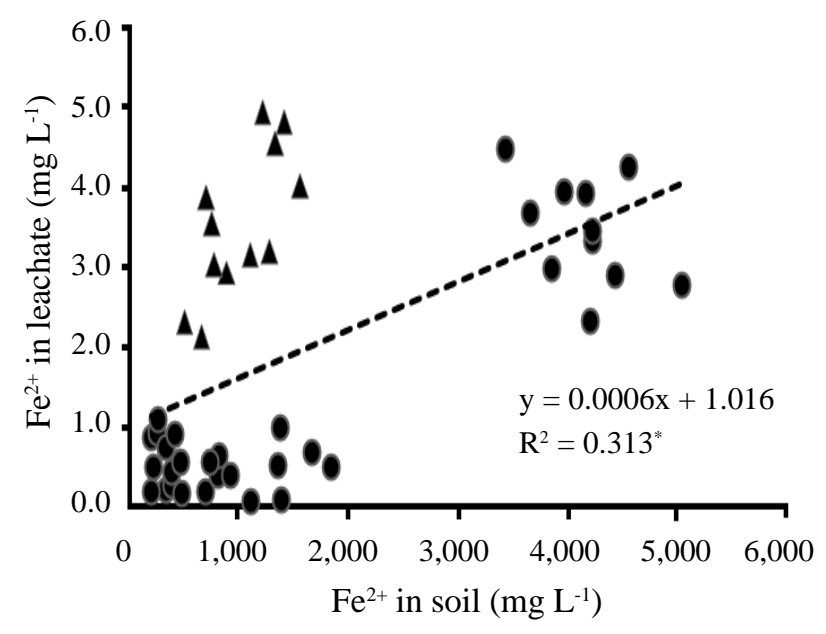

Figure 3. Relationship of $\mathrm{Fe}^{2+}$ in leachate and $\mathrm{Fe}^{2+}$ in soil as affected by fresh RS application on the soil which continuous application of RS and without application of RS.

Table 2. Selected chemical properties of water used in the experiment.

\begin{tabular}{lcccc}
\hline Water property & 2 WAP & 4 WAP & 6 WAP & 8 WAP \\
\hline $\mathrm{pH}$ & 3.2 & 3.1 & 3.5 & 4.1 \\
$\mathrm{P}\left(\mathrm{mg} \mathrm{PO}_{4}^{3-} \mathrm{L}^{-1}\right)$ & 0.06 & 0.08 & nd & nd \\
$\mathrm{Fe}\left(\mu \mathrm{g} \mathrm{Fe}^{2+} \mathrm{L}^{-1}\right)$ & 0.22 & nd & 0.10 & nd \\
\hline
\end{tabular}

Note $:$ nd $=$ not detectable. 
from the soil (Tan 2008). Solubility and mobility of organic Fe are higher than those of Fe hydroxides, and the Fe can move or be precipitated (Krachler et al.2005).

A correlation was found between $\mathrm{Fe}^{2+}$ in the leachate and $\mathrm{Fe}$ in the soil (Figure 3). The correlation between $\mathrm{Fe}^{2+}$ in the leachate and $\mathrm{Fe}^{2+}$ in the soil became weak because the concentration of $\mathrm{Fe}^{2+}$ measured in the leachate at $2 \mathrm{WAP}$ and $4 \mathrm{WAP}$ (points of the triangle) was equivalent to the concentration of $\mathrm{Fe}^{2+}$ as measured in the leachate at $6 \mathrm{WAP}$ and $8 \mathrm{WAP}$, in spite of the fact that $\mathrm{Fe}^{2+}$ concentrations for the latter observations were higher than at 2 WAP and 4 WAP (Fahmi et al.
2009). Application of RS increased leaching of Fe where $0.07-0.42 \% \mathrm{Fe}^{2+}$ in the soil were leached or $2-5$ folds higher than without fresh RS application which were only $0.03-0.14 \%$ (Table 3 ). These results showed that application of $\mathrm{OM}$ had a great role in increasing the leaching of $\mathrm{Fe}^{2+}$.

\section{The Effects of Rice Straw Application on the Leaching of $P$}

Phosphate concentration in leachate was very low (Figure 4), similar results was reported by Adhikari and Chen (2011) who measured P in leachate after applying $\mathrm{OM}$ and chemical fertilizer simultaneously, the value was well below the critical

Table 3. Percentage of $\mathrm{Fe}^{2+}$ leached from the soil as affected by fresh $\mathrm{RS}$ application.

\begin{tabular}{lcccc}
\hline Treatments & 2 WAP & $\begin{array}{c}\text { 4 WAP } \\
\mathrm{Fe}^{2+} \text { leached (\%) }\end{array}$ & $\begin{array}{c}\text { 6 WAP } \\
\text { 8 WAP }\end{array}$ \\
\hline Without fresh RS & 0.08 & 0.14 & 0.03 & 0.05 \\
Fresh RS added & 0.42 & 0.31 & 0.07 & 0.10 \\
\hline
\end{tabular}

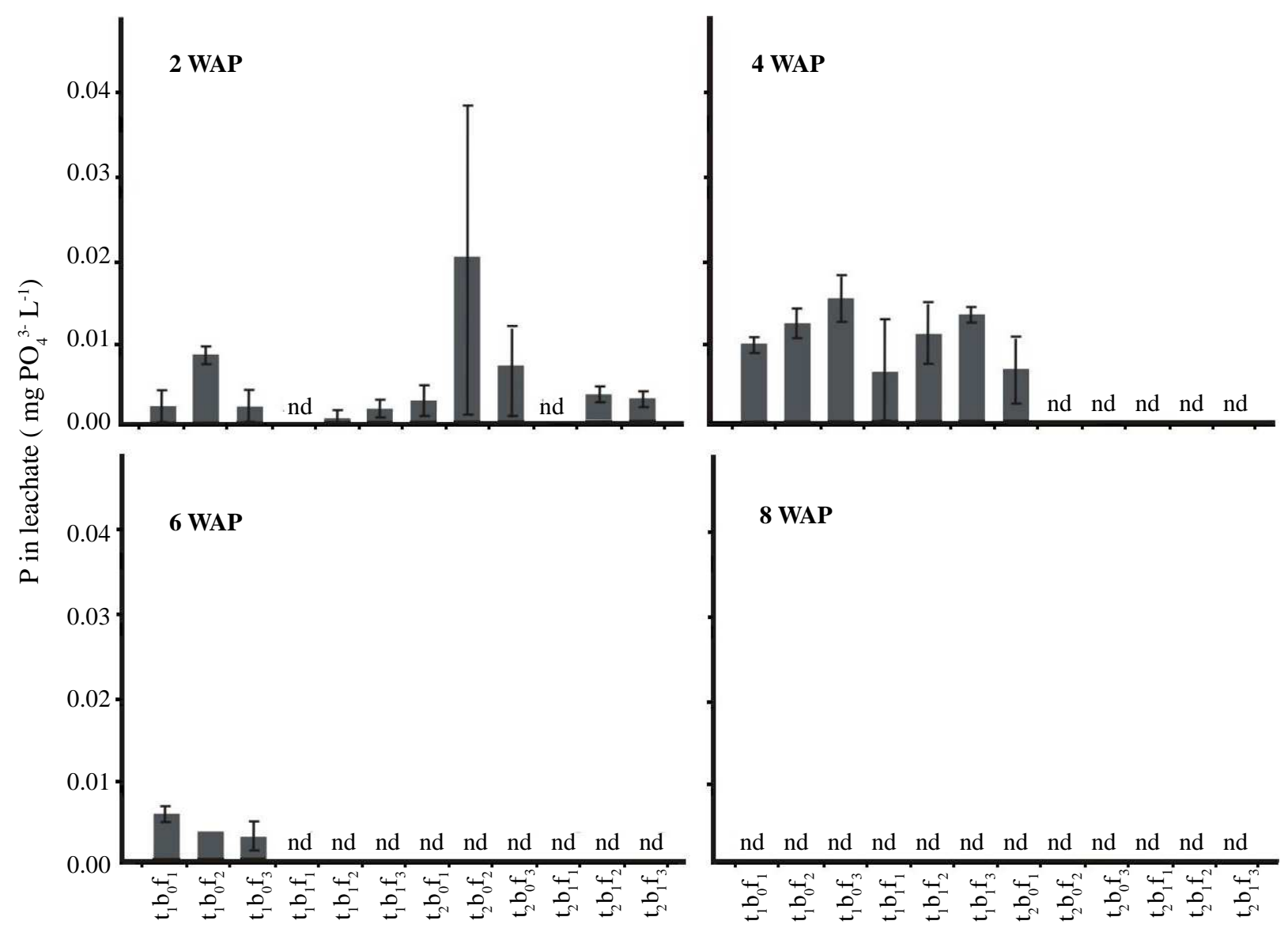

Treatments

Figure 4. Phosphate concentration in leachate was affected by fresh RS application with three rates of SP36 application on the soil which continuous application of RS and without application of RS. nd $=$ not detectable. 
level for environmental pollution. Loss of $\mathrm{P}$ through leaching was not affected by treatments at 2 WAP. This was considered due to the relatively high $\mathrm{P}$ concentration remaining in the soil resulting from $\mathrm{P}$ fertilizer application at planting such that the amount of $\mathrm{P}$ in the leachate was also relatively high. High $P$ availability in the soil would cause the $P$ to be easily lost through leaching and surface flow (Banach et al. 2009).

Fresh RS application to the soil which had continuously received $\mathrm{OM}$ application in the past five years decreased P loss at 4 WAP. Whereas at 6 WAP, loss of P only occurred from the soil without application of RS during the past five years, and without fresh RS application (Figure 3). On the other hand, $\mathrm{P}$ was not detectable in the leachate at $8 \mathrm{WAP}$ and this was considered due to the low concentration of $\mathrm{P}$ in the soil at 8 WAP (data not shown). These results showed that RS application decreased or prevented loss of P from the soil, and the capability of the RS in this regard is strongly determined by the $\mathrm{P}$ concentration in the soil solution and method of $\mathrm{P}$ fertilizer application (Kaiser et al. 2009; Sapek et al. 2009) and dissolved OM quantity (Sharma et al. 2010). Daverde et al. (2004) reported that combined application of inorganic and organic fertilizers decreased loss of P from agricultural soils.

There was a relationship between $\mathrm{P}$ concentration in the leachate and available $\mathrm{P}$ concentration in the soil (Figure 5). However the corelation between $\mathrm{P}$ in soil and $\mathrm{P}$ in leachate was significant but ccoefficients determination from the regression equation was somewhat low, and this was considered to be due to non-detectable $\mathrm{P}$ in leachates as measured at 6 and 8 WAP even though P concentrations in the soil were high (data not shown).

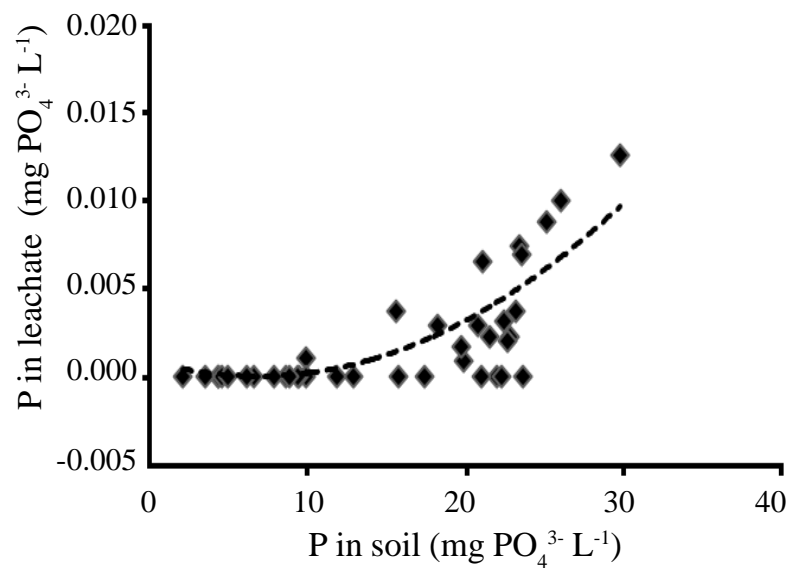

Figure 5. Relationship between $P$ in leachate and $P$ in soil that was affected by fresh RS application.

\section{The Effect of Rice Straw Application on the pH of Leachate}

The $\mathrm{pH}$ of leachate was significantly affected only by fresh RS application treatment factor (Figure 6), in which $\mathrm{pH}$ of leachate was consistently lower with application of fresh RS as compared to no fresh RS application. Application of OM in the form of RS would contribute organic acids upon decomposition which would result in acidification, and this was in agreement with the soil $\mathrm{pH}$ measured as indicated by the high value of $\mathrm{R}^{2}$ in Figure 7. Miller et al. (2010) reported that $\mathrm{pH}$ of leachate was corelated to acidification process in the soil solution.

Based on the results obtained as shown in Figure 6, pH of leachate increased with time for the duration of the observation, and this was considered to be related to the increases in soil $\mathrm{pH}$ (Figure 7).

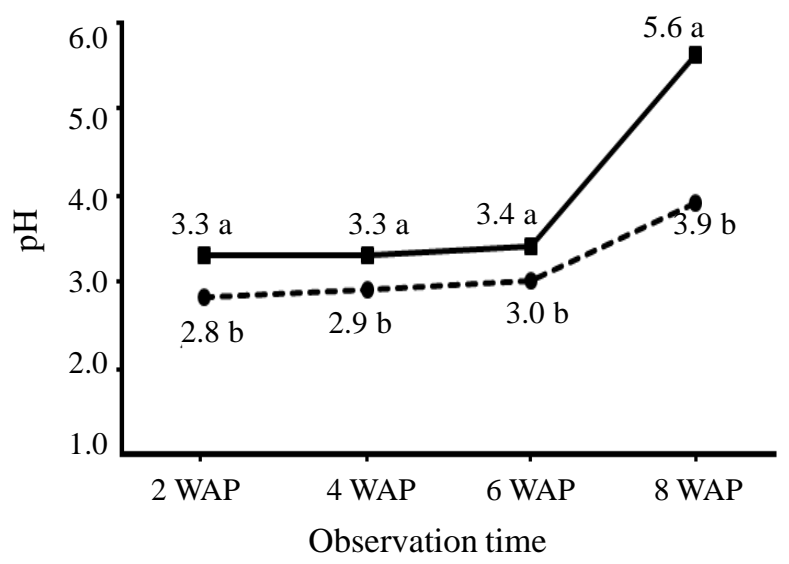

Figure 6. The effect of RS application as main factor on $\mathrm{pH}$ of leachate. The values that followed by same letter in same observation time is not different base on $5 \%$ level of DMRt. $-=$ Without fresh RS and $\boldsymbol{\bullet} \boldsymbol{\bullet} \cdot \boldsymbol{\bullet}=$ with Fresh RS.

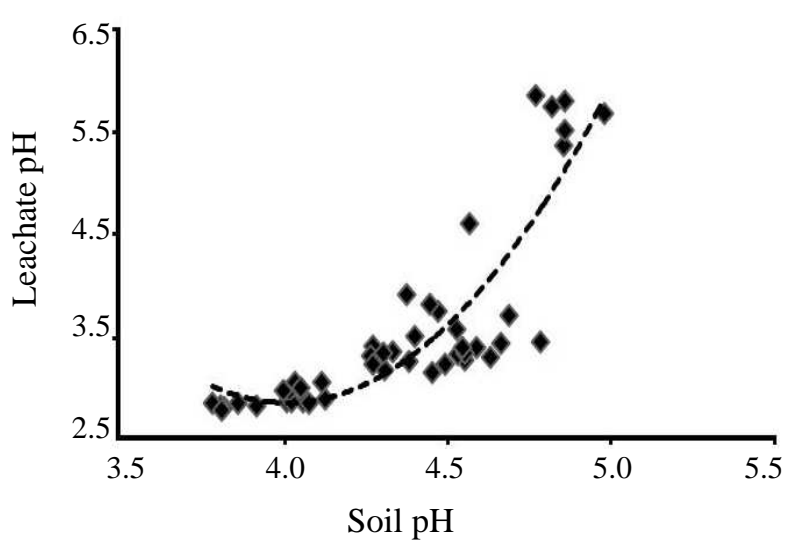

Figure 7. Relationship between leachate $\mathrm{pH}$ and soil $\mathrm{pH}$ that was affected by $\mathrm{RS}$ application. 
This was possibly due to the occurrence of sulfate reduction as the soil was continuously in a flooded condition for the two weeks. Very reduced soil condition as obtained in prolonged soil flooding could result in the reduction of sulfate, reduction of sulfate would decrease $\mathrm{H}^{+}$concentration in the soil as shown in the following equation (Reddy and DeLaune 2008) :

$2 \mathrm{SO}_{4}^{2-}+4 \mathrm{H}^{+}+2 \mathrm{CH}_{2} \mathrm{O} \rightarrow \mathrm{H}_{2} \mathrm{~S}+2 \mathrm{H}_{2} \mathrm{O}+1 / 4 \mathrm{CO}_{2}$

\section{CONCLUSIONS}

From the results obtained it was concluded that application of $\mathrm{OM}$ in the form of RS increased leaching of $\mathrm{Fe}^{2+}$ from the soil inspite of its low concentration in the soil. The amounts of $\mathrm{Fe}^{2+}$ leached ranged from $0.07 \%$ to $0.47 \%$ of the soil $\mathrm{Fe}^{2+}$. The application of RS was capable of decreasing or even preventing loss of $\mathrm{P}$ from the soil through leaching, but it was highly dependent on $\mathrm{P}$ concentration in the soil. Organic matter applied in the form of RS decreased $\mathrm{pH}$ of the leachate, and this was thought to be related to sulfate reduction.

\section{REFERENCES}

Adhikari KR and JS Chen. 2011. Combining compost with urea : nitrogen and phosphorus recovery by cabbage and leaching under imposed high rainfall condition in the greenhouse. Sci Res Essays 6 (4): 819-829.

Audebert A. 2006. Rice yield gap due to iron toxicity in West Africa. In: AAudebert, LT Narteh, P Kiepe, D Millar and B Beks (eds). Iron Toxicity in RiceBased Systems in West Africa. West Africa Rice Center (WARDA). Cotonou, Benin, pp. 18-33.

Balai Penelitian Tanah. 2005. Analisis Kimia Tanah, Tanaman, Air dan Pupuk. Badan Penelitian dan Pengembangan Pertanian. Departemen Pertanian. Bogor. 136 p. (in Indonesian).

Banach AM, K Banach, EJW Visser, Z Stepniewska, AJM Smits, JGM Roelofs and LPM Lamers. 2009. Effects of summer flooding on floodplain biogeochemistry in Poland ; implications for increased flooding frequency. Biogeochem 92: 247-262.

Daverde IC, AN Kravchenko, RG Hoeft, ED Nafziger, DG Bullock, JJ Warren and LC Gonzini. 2004. Phosphorus runoff from incorporated and surfaceapplied liquid swine manure and phosphorus fertilizer. J Environ Qual 33: 1535-1544.

Fahmi A, B Radjagukguk and BH Purwanto. 2009. Kelarutan fosfat dan ferro pada tanah sulfat masam yang diberi bahan organik jerami padi. J Tanah Trop 14 (2): 119-125 (in Indonesian).

Fuss CB, CT Dirscoll, CE Johnson, RJ Petras and TJ Fahey. 2011. Dynamics of oxidized and reduced iron in a nothern hardwood forest. Biogeochemistry 104: 103-119.
Haraguchi A. 2004. Factor acidifiying peat in Central Kalimantan, Indonesia. In : J Paivanen (ed). Wise Use of Peatlands. Proceedings of the $12^{\text {th }}$ International Peat Congress. Vol. 1. Tampere, Finland. pp. 638-643.

Kaiser DE, AP Mallarino and BL Allen. 2009. Runoff phosphorus loss immediately after poultry manure application as influenced by the application rate and tillage. J Environ Qual 38: 299-308.

Kang J, D Hesterberg and DL Osmond. 2009. Soil organic matter effects on phosphorus sorption: a path analysis. Soil Sci Soc Am J 73: 360-366.

Karlsson T and P Persson. 2010. Coordination chemistry and hydrolysis of $\mathrm{Fe}(\mathrm{III})$ in a peat humic acid studied by X-ray absorption spectroscopy. Geochim Cosmochim Ac 74: 30-40.

Kongchum M. 2005. Effect of Plant Residue and Water Management Practices on Soil Redox Chemistry, Methane Emission and Rice Productivity. [Dissertation]. Graduate Faculty of the Louisiana State University. USA.

Krachler R, F Jirsa and S Ayromlou. 2005. Factors influencing the dissolved iron input by river water to the open ocean. Biogeoscince 2: 311-315.

Miller FS, KL Kilminster, B Degens and GW Firns. 2010. Relationship between metals leached and soil type from potential acid sulphate soils under acidic and neutral conditions in Western Australia. Water Air Soil Pollut 205: 133-147.

Reddy KR and RD Delaune. 2008. The Biogeochemistry of Wetlands: Science and applications. CRC Press. New York, USA. 779 p.

Sapek A, B Sapek, S Chrzanowski and M Urbaniak. 2009. Nutrient mobilization and losses related to the groundwater level in low peat soils. Int J Environ Pollut 37 (4): 398-408.

Ojekami A, D Ige and X Hao. 2011. Phosphorus mobility in a soil with long term manure application. J Agric Sci 3 (3): 25-38.

Sharma R, RW Bell and MTF Wong. 2010. Processes of P mobility from Fitzgerald river catchment following application of different Prates. $19^{\text {th }}$ World Congress of Soil Science, Soil Solutions for a Changing World. 1-6 August 2010, Brisbane, Australia, pp. 109-112.

Tan KH. 2008. Soils in the Humid Tropic and Monsoon Region of Indonesia. CRC Press, Taylor and Francis Group. 557 p.

United State Environmental Agency (USEPA). 1986. Quality Criteria for Water. U.S. Goverment Printing Office, Washington D.C. 477 p.

Van-Es HM, RR Schindelbeck and WE Jokela. 2004. Effect of manure application timing, croping, and soil type on phosphorus leaching. J Environ Qual 33: 10701080 .

Watanabe T, LH Man, DM Vien, VT Khang, NN Ha, TB Linh and O Ito. 2009. Effects of continuous rice straw compost application on rice yield and soil properties in the Mekong Delta. Soil Sci Plant Nut 55 (6): 754-763. 